\title{
Osteoporoseforskning i Tromsø
}

\author{
Gro Karine Rosvold Berntsen, Monica Midtby, Tata M. Ringberg, \\ Ragnar M. Joakimsen, Jeanette H. Magnus, Anne Tollan, Vinjar Fønnebø og \\ Anne Johanne Søgaard
}

Tromsø Osteoporose Studie - TROST, Institutt for Samfunnsmedisin, 9037 Universitetet i Tromsø

Korrespondanse til Gro Karine Rosvold Berntsen

\begin{abstract}
SAMMENDRAG
Tromsø Osteoporose Studie (TROST) er knyttet til den fjerde store befolkningsundersøkelsen som gjennomføres i Tromsø. Vår tilgang til Tromsøundersøkelsenes kartlegging av livsstilsfaktorer, risikofaktorer for hjerte-kar sykdom samt flere kliniske- og laboratoriemålinger i befolkningen gjennom de siste 20 år gjør TROST til en unik studie i verdenssammenheng. Pr 1. oktober 1995 vil vi ha undersøkt bentetthet $\mathrm{i}$ underarm hos ca. 8000 personer. De fire delprosjektene som drives under TROST tar for seg bentetthet, biokjemiske markører for osteoporose, klinisk osteoporose og brudd. En nærmere presentasjon av hvert prosjekt gis i teksten.
\end{abstract}

Berntsen GKR, Midtby M, Ringberg TM, Joakimsen RM, Magnus JH, Tollan A, Fønnebø V, Søgaard AJ. Research on osteoporosis in Tromsø. Nor J Epidemiol 1995; 5 (2): 171-174.

\section{ENGLISH SUMMARY}

The Tromsø Osteoporosis Study (TROST) is part of the fourth large population based study being conducted in Tromsø, Norway. Our access to data from the current and previous Tromsø studies providing information on lifestyle factors, risk factors for cardiovascular disease, and several clinical and laboratory measurements in the population throughout the last 20 years makes TROST a unique study internationally. By October 1, 1995, we will have examined bone mineral density in the forearm of 8000 subjects. The four research projects under TROST focus on determinants of bone mineral density, biochemical markers of osteoporosis, clinical osteoporosis and determinants of osteoporotic fractures. A presentation of each project is given in the text.

\section{DEL 1 - PRESENTASJON AV TROMSø OSTEOPOROSE STUDIE}

\section{INNLEDNING}

Osteoporose påfører enkeltindivider store lidelser og samfunnet store omkostninger i form av brudd, sequelae etter brudd og for tidlig død. Vi har ca 8000 lårhalsbrudd i Norge pr. år og $20 \%$ av de som var selvhjulpne før bruddet blir sykehjemstrengende (1). 5 års overlevelse hos hoftebruddpasienter er $20 \%$ lavere enn i kontrollgrupper og de fleste av dødsfallene opptrer det første halvåret etter bruddet (2). Forekomst av osteoporose i en befolkning er ikke kjent, men bruddinsidensen indikerer at forekomsten nå øker og at den øker mer enn økningen av antall eldre skulle tilsi (3). Norge ligger, sammen med de andre nordiske land, på verdenstoppen i bruddfrekvens (4). Dette er en lidelse som til nå nesten utelukkende har vært beskrevet som den aldrende kvinnes sykdom, men bruddfrekvensen stiger nå mer hos menn enn blant kvinner (3). Når beinmassen først er redusert er behandlingsmulighetene små - derfor er forebyggende tiltak veien å gå videre. 


\section{TROMSØUNDERSØKELSENE}

Fire større befolkningsundersøkelser har vært gjennomført i Tromsø fra 1974 og fram til i dag. Den fjerde og foreløpig siste Tromsøundersøkelsen avsluttes 30. september 1995. Over en 20-årsperiode har en nå kartlagt risikofaktorer for hjerte/karsykdom, livsstils- og kostholdsopplysninger samt laboratoriedata for store deler av Tromsøs befolkning. Tromsøundersøkelsene gjør det derfor mulig å gjennomføre store epidemiologiske studier med endepunkter som bl.a bentetthet og brudd i løpet av relativt kort tid.

\section{TROST}

Når den fjerde Tromsøundersøkelsen skulle planlegges var det derfor naturlig å knytte osteoporoseforskning opp mot befolkningsundersøkelsen. Initiativet til Tromsø Osteoporose Studie (TROST) ble tatt av dr. med. J.H. Magnus, dr. med. A. Tollan, professor A.J. Søgaard og professor V. Fønnebø. Disse fire utgjør i dag styringsgruppen for TROST. TROST er et samarbeidsprosjekt mellom Regionsykehuset i Tromsø og Universitetet i Tromsø ved Institutt for Klinisk Medisin, og Institutt for Samfunnsmedisin.

\section{TROST har folgende formål:}

- $\AA$ kartlegge utbredelse av osteoporose i en befolkning.

- $\AA$ identifisere risikofaktorer relatert til lav bentetthet og osteoporotiske brudd.

- $\AA$ finne metoder for tidlig identifikasjon av personer med høy risiko for brudd.

- $\AA$ gjennomføre intervensjonsprosjekter som tar sikte på å forebygge osteoporotiske brudd.

\section{DATAINNSAMLING}

Alle kvinner i alderen 50-75 år, menn 55-75 år og et $5 \%$ utvalg av de øvrige aldersgruppene inviteres til bentetthetsstasjonen. Vi måler bentetthet i underarm, gripestyrke, fett $\mathrm{i}$ underhud på overarmen og tar blodprøver. I tillegg gjør vi en balansetest (bodysway) og en test av muskelstyrke (stoltest) på alle over 70 år. Alle deltakerne har fylt ut spørreskjema om bl.a. livsstil, sykelighet og kosthold på forhånd. Endel enkle kliniske undersøkelser og ultralydsundersøkelse av aorta carotis, aorta abdominalis og cor gjøres ved andre stasjoner i Tromsøundersøkelsen. Ved avslutningen av Tromsøundersøkelsen vil vi ha undersøkt rundt 8000 personer.

Fire delprosjekter fordelt på fire stipendiater er igang under TROST. Bentetthetsdataene bearbeides i prosjektet: "Osteoporose - utbredelse og etiologi". Kobling med laboratorieparametre gjøres i prosjektet "Biokjemiske markører for osteoporose." En oppfølging av deltakerne med lavest bentetthet gis i prosjektet "Osteoporose og helse". I det fjerde prosjektet: "Risikofaktorer for osteoporotiske brudd" blir et bruddregister for Tromsøområdet utarbeidet. En nærmere presentasjon av de enkelte delprosjektene følger etter denne introduksjonen til TROST.

\section{FRAMTIDIGE STUDIER}

Materialet som nå er samlet inn gir en enestående mulighet for prospektive, longitudinelle studier innen osteoporoseforskning. Vi planlegger i forste omgang å gjøre nye bentetthetsmålinger på studiepopulasjonen hvert annet år. Bruddregisteret vil bli vedlikeholdt slik at bruddinsidensen i studiepopulasjonen kan analyseres $\mathrm{i}$ forhold til bentetthet og andre risikofaktorer. Dette materialet er tenkt å utgjøre baseline-data i en rekke spennende prosjekter i framtida.

\section{DEL 2 - PRESENTASJON AV DELPROSJEKTENE}

\section{Cand. med. Gro K. Rosvold Berntsen: OSTEOPOROSE - UTBREDELSE OG ETIOLOGI.}

Med bakgrunn i de bentetthetsmålinger som er gjort $\mathrm{i}$ Tromsøundersøkelsen vil dette prosjektet spesielt konsentrere seg om følgende problemstillinger:

Hva er fordelingen av bentetthet i en totalbefolkning ?

Ingen andre undersøkelser er gjort på en så stor befolkning med såpass bred alderssammensetning og med begge kjønn representert i like stor grad. Tverrsnittsundersøkelsen vil gi ny informasjon spesielt i de yngste aldersgruppene og blant menn. Endringer i bentetthet i perimenopausen vil også kunne studeres nærmere.

\section{Er benskjørhet en livsstilssykdom?}

I de fleste studier finner man negative sammenhenger mellom røyking, alkohol, fysisk inaktivitet og bentetthet. Kostholdets betydning og sosioøkonomiske faktorers sammenheng med bentetthet er mer uklart og vil bli studert nærmere sammen med en gjennomgang av de mer velkjente risikofaktorene for osteoporose. 
Er lav bentetthet en markør på høyere sykelighet?

Lav bentetthet og osteoporotiske brudd har vist seg å forutsi død av ikke-traumatisk årsak $(5,6)$. Grunnen til denne sammenhengen er ikke kjent. Tidligere og aktuell sykdom vil sammenholdes med bentetthet.

Kan en østrogen-skåre forutsi bentetthet?

En østrogen-skåre som uttrykker kvinnens samlede østrogeneksponering kan kanskje senere brukes sammen med bentetthetsmålingen for å forutsi framtidig bentetthet og risiko for brudd.

\section{Er vi blitt for tynne?}

Vår tids fokusering på slanking, mager mat og fedme har bidratt til en reduksjon av vekt $\mathrm{i}$ forhold til høyde. Mange studier viser at overvektige har høyere bentetthet enn slanke og at høy body-mass-index beskytter mot osteoporotiske brudd (7). En vil se på forskjellige mål for fettinntak i kosten og fedme og relatere dette til bentetthet.

\section{Cand. med. Monica Midtby: SERUMMARKØRER FOR BENMETABOLISME - DIAGNOSTISK OG PROGNOSTISK VERDI VED OSTEOPOROSE?}

Fordi osteoporose er en sykdom der behandling er vanskelig, men mulighet for forebygging er god, er tidlig diagnostikk viktig. Det er derfor behov for en ikke-invasiv, sensitiv og lett tilgjengelig metode for registrering av endringer i skjelettmetabolismen. En slik metode vil kunne brukes til å identifisere risikoindivider og evaluere terapieffekt. Til dette formål er måling av biokjemiske markører lovende (8).

I benvev foregår en livslang syklisk prosess av nedbrytning og oppbygning. Dette medfører at ulike bindevevskomponenter frigjøres til sirkulasjonen, og disse kan benyttes som markører for grad av benturnover. De mest aktuelle makører for bensyntese er benspesifikk ALP, benmatrixproteinet Osteocalcin og C-terminalt propeptid av type I collagen (PICP). For benresorbsjon er collagen kryssbindingene Pyridinolin/deoksypyridinolin (PYR/DPD) og C-terminalt telopeptid av type I collagen (ICTP) mest aktuelle.

Ingen av disse er i dag i klinisk bruk, hvilket dels er betinget i manglende kunnskap om verdier og variasjoner i en normalbefolkning. Det er derfor et klart behov for en systematisk studie av bindevevsmarkører i en større populasjon.
Dette delprosjektet blir hovedsakelig et laboratoriearbeid der ulike bindevevsmarkører skal analyseres i sera til personene fra TROST. Resultatene vil så bli koblet opp mot opplysninger om alder, kjønn, BMI (body mass index) og bentetthet. Relasjon til kalsiumstoffskiftet og lipidprofil vil også vurderes. Når man har funnet frem til bindevevsmarkører som tilfredsstiller kravene til sensitivitet og spesifisitet (9), kan det unike materialet som er og vil bli innsamlet kunne gi svar på spørsmål som:

- om det ut fra en enkel blodprøve er mulig å identifisere kvinner som postmenopausalt har behov for østrogensubstitusjon fordi de er såkalt "fastloosers" (10).

- om nivået av bindevevsmarkører ellers korrelerer med bentetthet og utvikling av osteoporose og med bruddinsidens.

- om markørene uttrykker en årstidsvariasjon av benmetabolismen.

- om kjente og mistenkte risikofaktorer for osteoporose også gjenspeiles i nivået av serummarkørene.

Cand. med. \& real. Tata M. Ringberg: OSTEOPOROSE OG HELSE

1. Effekt af helseundersøgelse og sygdomsinformation på livskvalitet.

2. Får man osteoporose fordi man er gammel - eller bliver man gammel fordi man har osteoporose?

Det følgende projekt har som formål at kortlegge effekten af intervention $\mathrm{i}$ form af grundig klinisk undersøgelse, information om osteoporose og opfølgning på en gruppe mennesker som er valgt ud fra normalmaterialet på grund af sin specielt lave bentethed.

Helseoplysning er i seg selv en interventionsmetode med ikke uvæsentlige sideeffekter. TROST representerer i den forbindelse en enestående mulighed for en direkte studie af hvordan information og rådgivning pr. se. indvirker på livskvalitet og såvel subjektivt velbefinnende som objektiv helsetilstand.
Osteoporosens årsak er lidet kendt. En hypotese er at sykdommen er en af flere manifestationer af tilgrundliggende konstitutionel bindevævspatologi med præmatur aldring som fællesnævner. I forbindelse med de kliniske undersøgelser vil man derfor forsøge at kvantificere og rangere forskellige tegn på præmatur aldring i form af en indeks, "Klinisk alders score" med det formål at konstruere et prognostisk risikomål for utvikling av osteoporose. 
Cand. med. Ragnar Martin Joakimsen: KAN ENDRET LIVSSTIL GI REDUSERT RISIKO FOR BRUDD? En studie av bruddinsidens i Tromsø 1980-94 korrelert til ulike risikofaktorer og endringer av disse.

Ved å koble opplysninger fra de tre store befolkningsundersøkelsene i Tromsø i henholdsvis 1974, 1979/80 og 1986/87 til opplysninger fra røntgenarkivet ved Regionsykehuset i Tromsø vedrørende brudd hos innbyggere over 40 år, ønsker vi gjennom en historisk prospektiv studie å undersøke følgende:

\section{1. ØKER BRUDDINSIDENSEN I TROMSØ?}

Avgrensning: Vi vil se på insidensen av alle typer brudd hos innbyggere etter fylte 40 år i perioden 1980-1994.

Nytteverdi: Det er tidligere påvist en økning i lårhalsbrudd i Troms frem til 1989. Det vil være svært interessant å finne ut om alle typer brudd hos eldre er i økning. Gjennom studien kan vi i så fall kartlegge fellesfaktorer for en slik utvikling av ulike bruddtypers insidens.

\section{HVEM ER DET SOM FÅR BRUDD?}

Avgrensning: $\mathrm{Vi}$ vil beskrive bruddinsidensen i Tromsø 1980-1994 og se dens variasjon i forhold til alder, kjønn, utdannelsesnivå, sosioøkonomisk status, bosted, samtidig kronisk sykdom, livsstilsfaktorer, vekt og høyde. Bruddpasientene vil bli studert $\mathrm{i}$ forhold til alle innbyggere i Tromsø i samme aldersgruppe.

Nytteverdi: Få tidligere studier har vært befolkningsbaserte, og de har stort sett omhandlet brudd i lårhals. $\mathrm{Vi}$ vil gjennom en befolkningsbasert undersøkelse kunne etablere ny viten om de nevnte faktorers innvirkning på alle typer brudd hos kvinner 40-64 år og menn 40-69 år.

\section{KAN ENDRET LIVSSTIL GI ENDRET RISIKO FOR BRUDD?}

Avgrensning: Endring av bruddinsidens i forhold til endring i røyking, kosthold, kolesterol, fysisk aktivitet, alkohol- og kaffeforbruk i perioden 1974-1987.

Nytteverdi: En vet at livsstilsfaktorer sannsynligvis innvirker på risiko for å få brudd. Imidlertid vet en lite om evt. endring av livsstil vil gi en endret bruddrisiko. Her vil vi få kunnskap om faktiske endringer i nevnte faktorer medfører endret risiko for brudd. Dette vil være viktig viten for senere intervensjon.

\section{KAN REDUKSJON I KROPPSHØYDE FORUTSI SENERE BRUDD?}

Avgrensning: Reduksjon i kroppshøyde kan være et mål for brudd eller deformiteter i columna, og det er kjent at eksisterende brudd er en sterk prediktor for senere brudd generelt. Vi vil studere om reduksjon i målt kroppshøyde i perioden 1974-1987 kan predikere senere brudd.

Nytteverdi: Hvis det viser seg at høydereduksjon kan forutsi brudd, så vil kunnskapen om dette være nyttig for å identifisere risikogrupper.

\section{KAN FORHOLD I BARNDOMMEN AVGJØ- RE OM EN FÅR BRUDD SENERE I LIVET?}

Avgrensning: Vi vil se på sammenheng mellom bruddinsidens og økonomi i barneårene.

Nytteverdi: Man vet at forhold i oppveksten har betydning for senere bentetthet. Liten vektøkning i første leveår er assosiert med lav bentetthet senere, og øt inntak av mettet fett hos ungdommer gir høyere bentetthet. Her kan vi få kunnskap om oppvekstvilkår også påvirker senere tendens til brudd.

\section{REFERANSER}

1. Ahlo A. Hoftebrudd. Tidskr Nor Lageforen 1993; 113: 1445.

2. Cooper C. Epidemiology and public health impact of osteoporosis. Baillieres Clin Rheumatol 1993; 7: 45977.

3. Falch JA, Kaastad TS, Bøhler G, Espeland J, Sundsvold OJ. Secular increase and geographical differences in hip fracture incidence in Norway. Bone 1993; 14: 643-5.

4. Falch JA, Ilebekk A, Slungaard U. Epidemiology of hip fractures in Norway. Acta Orthop Scand 1985; 56: 12-16.

5. Cooper C, Atkinsen EJ, Jacobsen SJ, O'Fallon WM, Melton LJ III. Population-based study of survival after osteoporotic fractures. Am J Epidemiol 1993; 137: 1001-5.

6. Browner WS, Seeley DG, Vogt TM, Cummings SR. Non-trauma mortality in elderly women with low bone mineral density. Lancet 1991; 338: 355-58.

7. Meyer HE, Tverdal A, Falch JA. Body height, body mass index and fatal hip fractures: 16 years followup of 674000 Norwegian women and men. Epidemiology 1995; 6: 299-305.

8. Eriksen EF, Brixen K, Charles P. New markers of bone metabolism: clinical use in metabolic bone disease. Eur J Endocrinol 1995; 132: 251-63.

9. Taylor AK, Lueken SA, Libanati C, Baylink DJ. Biochemical markers of bone turnover for the clinical assessment of bone metabolism. Osteoporosis 1994; 20: 589-607.

10. Recent advances in biochemical markers of bone turnover. Clin Chem 1994; 40: 1994-95. 